\title{
Upaya Meningkatkan Daya Ingat Tentang Materi Keseimbangan Lingkungan Dengan Menerapkan Teknik Mind Mapping
}

\author{
Siti Rochanah \\ SDN Kendangsari I/276 Surabaya \\ Jl. Kendangsari Blok S No.26, Kecamatan Tenggilis Mejoyo, Kota Surabaya \\ rochanah.siti70@gmail.com
}

\begin{abstract}
This study aims to determine whether nor not there is an increase in the memory of the Environmental Balance material through the application of Mind Mapping techniques to students of Class 4-C SD Negeri Kendangsari I/276 Surabaya, and to determine how much the increase in the memory of the Environmental Balance material through the application of Mind Mapping techniques to students. Class 4-C SD Negeri Kendangsari I/276 Surabaya. This research was conducted to overcome the problem of low memory experienced by students of Class 4-C SD Negeri Kendangsari I/276 Surabaya. Therefore, the author as a teacher in the class tries to apply the Mind Mapping technique which focuses on student learning activities in order to get educational values, knowledge in learning and maximum memory. The action research was carried out in two learning cycles and, based on the exposure to the results of the research and discussion, it can be concluded that there is an increase in the memory of the Environmental Balance material through the application of Mind Mapping techniques in Class 4-C students of SD Negeri Kendangsari I/276 Surabaya. Improved memory of Environmental Balance material through the application of Mind Mapping techniques in Grade 4-C students of SD Negeri Kendangsari $\mathrm{I} / 276$ Surabaya an average of $25 \%$
\end{abstract}

Keywords: Memory, Environmental Balance, Mind Mapping Techniques

\begin{abstract}
Abstrak
Penelitian ini bertujuan untuk mengetahui ada tidaknya peningkatan daya ingat materi Keseimbangan Lingkungan melalui penerapan teknik Mind Mapping pada siswa Kelas 4-C SD Negeri Kendangsari I/276 Surabaya, dan untuk mengetahui seberapa besar peningkatan daya ingat materi Keseimbangan Lingkungan melalui penerapan teknik Mind Mapping pada siswa Kelas 4-C SD Negeri Kendangsari I/276 Surabaya. Penelitian ini dilaksanakan untuk mengatasi permasalahan rendahnya daya ingat yang dialami siswa Kelas 4-C SD Negeri Kendangsari I/276 Surabaya. Oleh karenanya, penulis sebagai guru pada kelas tersebut mencoba untuk menerapkan teknik Mind Mapping yang menitikberatkan pada aktivitas belajar siswa agar mendapatkan nilai-nilai pendidikan, pengetahuan dalam belajar dan daya ingat yang lebih maksimal. Penelitian tindakan dilaksanakan dalam dua siklus pembelajaran, dan berdasarkan paparan hasil penelitian dan pembahasan, dapat dirumuskan kesimpulan penelitian bahwa Ada peningkatan daya ingat materi Keseimbangan Lingkungan melalui penerapan teknik Mind Mapping pada siswa Kelas 4-C SD Negeri Kendangsari I/276 Surabaya. Peningkatan daya ingat materi Keseimbangan Lingkungan melalui penerapan teknik Mind Mapping pada siswa Kelas 4-C SD Negeri Kendangsari I/276 Surabaya rata-rata sebesar 25\%.
\end{abstract}

Kata kunci: Daya Ingat, Keseimbangan Lingkungan, Teknik Mind Mapping

Copyright (c) 2021 Siti Rochanah

Corresponding author: Siti Rochanah

Email Address: rochanah.siti70@gmail.com (J1. Kendangsari Blok S No.26, Kec. Tenggilis Mejoyo, Surabaya)

Received 09 September 2021, Accepted 06 October 2021, Published 19 November 2021

\section{PENDAHULUAN}

Mengingat merupakan proses memanggil kembali informasi yang telah disimpan di dalam otak. Otak merupakan tempat menerima, menyimpan kemudian mengenali informasi yang ada, artinya otak adalah pusat ingatan manusia (Markowitz dan Jensen, 2002). Di dalam otak tersimpan berbagai macam informasi. Bermacam-macam jenis ingatan ada dalam otak manusia. Selama otak dalam keadaan sehat manusia akan selalu melakukan proses mengingat. Otak tidak bekerja sendirian pada saat proses mengingat, perlu adanya kerjasama dengan organ lain diantaranya pancaindera. 
Pancaindera menerima informasi kemudian diantar ke otak diolah dan disimpan. Lalu pada saat-saat tertentu bila dibutuhkan otak akan mengeluarkan informasi tersebut sebagai bentuk mengenali.

Kemampuan mengingat adalah kemampuan memori memanggil kembali fakta dan informasi yang pernah diketahui atau dipelajari. Daya ingat adalah suatu kemampuan untuk mengingat apa yang telah diketahui (Gie dalam Wulandari, 2009:2). Menurut R. Teti Rostikawati (dalam Arfiya, 2011), ingatan merupakan suatu proses pemberian kode-kode terhadap informasi dan pemanggilan informasi kembali ketika informasi tersebut dibutuhkan. Sebagian psikologi berpendapat bahwa ingatan adalah aktifitas otak dalam merekam, menyimpan dan memutar kembali apa yang telah terjadi pada masa lampau, baik berupa pengetahuan, pemikiran, kecenderungan, tingkah laku dan aktivitas (gerakan). Seseorang dapat mengingat suatu informasi yang telah dipelajari pada waktu yang lalu. Semakin banyak informasi yang diperoleh seseorang berarti semakin sering terjadi kaitan antara informasi satu dengan informasi yang lain. Setiap informasi yang dipelajari telah meninggalkan semacam jejak dalam otak manusia dan jejak itulah yang akan dikeluarkan oleh otak berupa informasi terdahulu yang telah tersimpan. Hal tersebut terjadi pada saat seseorang mengingat informasi.

Dalam proses belajar mengajar yang dilakukan secara daring, penggunaan metode pengajaran yang tepat akan sangat berpengaruh terhadap ketercapaian pemahaman siswa, dan daya ingat menjadi kunci dari konstruksi pemahaman tersebut. Tentunya semua metode pengajaran yang pernah diterapkan selama ini mempunyai kelebihan dan kekurangan. Terlepas dari semua itu, metode pengajaran yang sering diterapkan oleh guru-guru kita saat ini adalah cenderung untuk hanya mengaktifkan salah satu sisi otak sang murid saja. Karena pada hakekatnya otak manusia terbagi menjadi dua, yaitu otak kiri dan otak kanan.

Kedua belahan otak manusia ini memiliki tugas dan cara kerja yang berbeda. Otak kiri bekerja untuk hal-hal yang terkait dengan kata, angka dan daftar. Sementara otak kanan berkerja untuk hal-hal yang terkait dengan kesadaran, imajinasi, warna, keindahan. Sebagaimana dua kaki dan tangan, aktivitas manusia akan mudah dikerjakan bila kedua pasang organ tersebut bekerja dengan baik. Tentunya berjalan dengan dua kaki akan jauh lebih optimal dibandingkan dengan jalan satu kaki. Demikianlah perumpamaannya dengan otak kita.

Begitu juga siswa dalam belajar, jika siswa bisa mengaktifkan dua sisi otaknya secara efektif, maka penulis yakin mereka akan dengan mudah menerima pelajaran yang diberikan guru kepada siswa. Bukan hanya itu, kemampuan logika anak akan lebih berkembang ketimbang mereka harus menghafal kata demi kata dan kalimat demi kalimat. Metode pengajaran/pemberlajaran yang dapat mengoptimalakan kedua belah sisi otak manusia tersebut adalah metode Mind Mapping (Peta Pikiran).

Permasalahan rendahnya daya ingat juga dialami siswa Kelas 4-C SD Negeri Kendangsari I/276 Surabaya. Oleh karenanya, penulis sebagai guru pada kelas tersebut mencoba untuk menerapkan teknik Mind Mapping yang menitikberatkan pada aktivitas belajar siswa agar mendapatkan nilai-nilai 
pendidikan, pengetahuan dalam belajar dan daya ingat yang lebih maksimal.

Penelitian ini bertujuan untuk mengetahui ada tidaknya peningkatan daya ingat materi Keseimbangan Lingkungan melalui penerapan teknik Mind Mapping pada siswa Kelas 4-C SD Negeri Kendangsari I/276 Surabaya, dan untuk mengetahui seberapa besar peningkatan daya ingat materi Keseimbangan Lingkungan melalui penerapan teknik Mind Mapping pada siswa Kelas 4-C SD Negeri Kendangsari I/276 Surabaya.

\section{Pembelajaran IPA di SD}

Ilmu Pengetahuan Alam (IPA) juga disebut dengan istilaih sains yang berasal dari bahasa latin Scientia yang arti harfiahnya adalah pengetahuan. Sains menurut Suyoso (1998:23) merupakan "pengetahuan hasil kegiatan manusia yang bersifat aktif dan dinamis tiada henti-hentinya serta diperoleh melalui metode tertentu yaitu teratur, sistematis, berobjek, bermetode dan berlaku secara universal".

Menurut Abdullah (1998:18), IPA merupakan pengetahuan teoritis yang diperoleh atau disusun dengan cara yang khas atau khusus, yaitu dengan melakukan observasi, eksperimentasi, penyimpulan, penyusunan teori, eksperimentasi, observasi dan demikian seterusnya kait mengkait antara cara yang satu dengan cara yang lain. Dari pendapat di atas maka dapat disimpulkan bahwa IPA merupakan pengetahuan dari hasil kegiatan manusia yang diperoleh dengan menggunakan langkah-langkah ilmiah yang berupa metode ilmiah dan didapatkan dari hasil eksperimen atau observasi yang bersifat umum sehingga akan terus di sempurnakan.

Dalam pembelajaran IPA mencakup semua materi yang terkait dengan objek alam serta persoalannya. Ruang lingkup IPA yaitu makhluk hidup, Keseimbangan Lingkungan, bumi dan alam semesta serta proses materi dan sifatnya. Dari uraian di atas mengenai pengertian pendidikan dan IPA, maka pendidikan IPA merupakan penerapan dalam pendidikan dan IPA untuk tujuan pembelajaran termasuk pembelajaran di SD.

Sedangkan pendidikan IPA menurut Sumaji (1998:46) merupakan "suatu ilmu pegetahuan social yang merupakan disiplin ilmu bukan bersifat teoritis melainkan gabungan (kombinasi) antara disiplin ilmu yang bersifat produktif". Dari kedua pengertian di atas dapat disimpulkan bahwa pendidikan IPA merupakan suatu usaha yang dilakukan secara sadar untuk mengungkap gejala-gejala alam dengan menerapkan langkah-langkah ilmiah serta untuk membentuk kepribadian atau tingkah laku siswa sehingga siswa dapat memahami proses IPA dan dapat dikembangkan di masyarakat.

Pendidikan IPA menjadi suatu bidang ilmu yang memiliki tujuan agar setiap siswa memiliki kepribadian yang baik dan dapat menerapkan sikap ilmiah serta dapat mengembangkan potensi yang ada di alam untuk dijadikan sebagai sumber ilmu dan dapat diterapkan dalam kehidupan sehari - hari. Proses dalam pengertian disini merupakan interaksi semua komponen atau unsur yang terdapat dalam belajar mengajar yang satu sama lainnya saling berhubungan (inter independent) dalam ikatan untuk mencapai tujuan (Usman, 2000: 5). Belajar diartikan sebagai proses perubahan tingkah laku pada diri 
Upaya Meningkatkan Daya Ingat Tentang Materi Keseimbangan Lingkungan Dengan Menerapkan Teknik Mind Mapping, Siti Rochanah

individu berkat adanya interaksi antara individu dengan lingkungannya. Hal ini sesuai dengan yang diutarakan Burton bahwa seseorang setelah mengalami proses belajar akan mengalami perubahan tingkah laku, baik aspek pengetahuannya, keterampilannya, maupun aspek sikapnya. Misalnya dari tidak bisa menjadi bisa, dari tidak mengerti menjadi mengerti (dalam Usman, 2000: 5).

Proses belajar mengajar merupakan suatu inti dari proses pendidikan secara keseluruhan dengan guru sebagai pemegangn peran utama. Proses belajar mengajar merupakan suatu proses yang mengandung serangkaian perbuatan guru dan siswa atas dasar hubungan timbal balik yang berlangsung dalam situasi edukatif untuk mencapai tujuan tertentu. Interaksi atau hubungan timbal balik antara guru dan siswa itu merupakan syarat utama bagi berlangsungnya proses belajar mengajar (Usman, 2000: 4).

Belajar dapat membawa suatu perubahan pada individu yang belajar. Perubahan ini merupakan pengalaman tingkah laku dari yang kurang baik menjadi lebih baik. Pengalaman dalam belajar merupakan pengalaman yang dituju pada hasil yang akan dicapai siswa dalam proses belajar di sekolah. Menurut Poerwodarminto (1991: 768), prestasi belajar adalah hasil yang dicapai (dilakukan, dikerjakan), dalam hal ini prestasi belajar merupakan hasil pekerjaan, hasil penciptaan oleh seseorang yang diperoleh dengan ketelitian kerja serta perjuangan yang membutuhkan pikiran.

Dengan demikian dapat dikatakan bahwa prestasi belajar yang dicapai oleh siswa dengan melibatkan seluruh potensi yang dimilikinya setelah siswa itu melakukan kegiatan belajar. Pencapaian hasil belajar tersebut dapat diketahui dengan megadakan penilaian tes hasil belajar. Penilaian diadakan untuk mengetahui sejauh mana siswa telah berhasil mengikuti pelajaran yang diberikan oleh guru. Di samping itu guru dapat mengetahui sejauh mana keberhasilan guru dalam proses belajar mengajar di sekolah.

\section{Daya Ingat}

Daya ingat merupakan alih bahasa dari memory. Pada umumnya para ahli memandang daya ingat sebagai hubungan antara pengalaman dengan masa lalu (Walgito, 2004). Seseorang dapat mengingat sesuatu pengalaman yang telah terjadi atau pengetahuan yang telah dipelajari pada masa lalu (Afiatin, 2001). Drever (dalam Walgito, 2004) menjelaskan memori adalah salah satu karakter yang dimiliki oleh makhluk hidup, pengalaman berguna apa yang kita lupakan yang mana mempengaruhi perilaku dan pengalaman yang akan datang, yang mana ingatan itu bukan hanya meliputi recall (mengingat) dan recognition (mengenali) atau apa yang disebut dengan menimbulkan kembali ingatan.

Santrock menjelaskan bahwa daya ingat adalah unsur perkembangan kognitif, yang memuat seluruh situasi yang di dalamnya individu menyimpan informasi yang diterima sepajang waktu (Atkinson, 2000). Daya ingat (memory) merujuk pada kemampuan individu memiliki dan mengambil kembali suatu informasi dan juga struktur yang mendukungnya serta suatu bentuk kompetensi, memori juga memungkinkan individu memiliki identitas diri (Wade, 2008). 
Menurut Tulving, daya ingat adalah cara-cara yang dengannya individu dapat mempertahankan dan menarik pengalaman dari masa lalu untuk digunakan saat ini. Sedangkan Porter \& Hernacki menjelaskan bahwa daya ingat adalah suatu kemampuan untuk mengingat apa yang telah diketahui. Sebelum seseorang mengingat suatu informasi atau sebuah kejadian dimasa lalu, ada beberapa tahapan yang harus dilalui ingatan tersebut untuk dapat muncul kembali. Atkinson (2000) berpendapat bahwa, para ahli psikologi membagi tiga tahapan ingatan, yaitu:

1. Memasukan pesan dalam ingatan (encoding). Mengacu pada cara individu mentransformasikan input fisik indrawi menjadi sejenis representasi mental dalam memori.

2. Penyimpanan ingatan (storage). Mengacu pada cara individu menahan informasi yang sudah disimpan dalam memori.

3. Mengingat kembali (retrieval). Mengacu pada bagaiman individu memperoleh akses menuju informasi yang sudah disimpan dalam memori.

Para ahli sepakat bahwa proses memori tidak hanya seperti yang dijelaskan pada tersebut diatas tetapi tergantung dari mana memori dilihat, seperti penjelasan Davis (dalam Hamberg, 2006), menurutnya informasi yang masuk harus melalui tiga tahapan yang belum disimpan dalam waktu yang lama. Tiga tahapan tersebut adalah:

1. Sebagian besar aliran diterima alat indera-percakapan, sensasi sentuhan ataupun bau yang masuk ke hidung, semuanya mampir ke otak hanya sedetik saja dan selanjutnya lenyap lagi. Dapat dikatakan kesan tersebut tampak lenyap.

2. Tahap kedua disebut memori jangka pendek (short term memory). Memori ini terpilih untuk disimpan karena individu memberikan perhatian padanya. Ketertarikan, kegelisahan dan kegembiraanlah yang membedakannya.

3. Tahap selanjutnya adalah memori jangka panjang (long term memory). Memori jangka panjang biasanya rentan terhadap kelemahan otak seiring usia beranjak tua.

Proses mengingat atau memori banyak dipengaruhi oleh berberapa faktor (Ahmadi, 2004) yaitu:

1. Faktor Individu. Proses mengingat dipengaruhi dari dalam individu seperti sifat, keadaan jasmani, keadaan rohani dan umur. Mengingat akan lebih efektif apabila individu memiliki minat yang besar, motivasi yang kuat, memiliki metode tertentu dalam pengamatan dan pembelajaran, dan memiliki kondisi fisik dan kesehatan yang baik.

2. Faktor objek yang diingat. Sesuatu yang memiliki organisasi dan struktur yang jelas, mempunyai arti, mempunyai keterkaitan dengan individu, mempunyai intensitas rangsangan yang cukup kuat lebih mudah diingat oleh seseorang.

3. Faktor Lingkungan. Proses mengingat akan lebih efektif apabila ada lingkungan yang menunjang dan terhindar dari adanya gangguangangguan. 
Daya ingat erat kaitannya dengan memori yaitu tempat informasi dikumpulkan. Informasi ini dapat diperoleh dari indera penglihatan, pendengaran, perabaan, pengecapan dan penciuman. Untuk mempertahankan informasi didalam memori ada berbagai cara yang dapat dilakukan yaitu dengan pengulangan, pembiasaan, memberikan pemahaman, memberikan motivasi, dan mencatat.

Dengan menstimulasi daya ingat pada anak, akan banyak manfaat yang dapat kita peroleh yaitu dapat meningkatkan kosentrasi, semakin diasah kemampuan mengingat, semakin besar memori yang disediakan otak untuk menyimpan informasi, anak dapat belajar memahami, menumbuhkan kepercayaan diri mereka, serta melatih kemampuan bahasa sebagai bekal di masa depannya kelak

\section{Teknik Mind Mapping}

Mind Mapping atau peta pikiran adalah suatu tekhnik pembuatan catatan-catatan yang dapat digunakan pada situasi, kondisi tertentu, seperti dalam pembuatan perencanaan, penyelesaian masalah, membuat ringkasan, membuat struktur, pengumpulan ide-ide, untuk membuat catatan, kuliah, rapat, debat dan wawancara (Svantesson, 2004: 1).

Konsep Mind Mapping asal mulanya diperkenalkan oleh Tony Buzan tahun 1970-an. Menurutnya mind map adalah sistem penyimpanan, penarikan data, dan akses yang luar biasa untuk perpustakaan raksasa, yang sebenarnya ada dalam otak manusia yang menakjubkan (Buzan, 2009: 12). Mind map adalah cara termudah untuk menempatkan informasi ke dalam otak dan mengambil informasi keluar otak-Mind Map adalah cara mencatat yang kreatif, efektif, dan secara harfiah akan "memetakan" pikiran-pikiran kita.

Pemetaan pikiran yang dikemukakan oleh Buzan ini didasarkan pada kenyataan bahwa otak manusia terdiri dari satu juta juta sel otak atau setara dengan 167 kali jumlah manusia di bumi, sel-sel otak tersebut terdiri dari beberapa bagian, ada bagian pusat (nukleus) dan ada sejumlah bagian cabang yang memencar ke segala arah, sehingga tampak seperti pohon yang menumbuhkan cabang ke sekelilingnya (Buzan, 2009:30).

Sama seperti peta jalan, Mind Map akan memberi pandangan meyeluruh pokok masalah atau area yang luas, memungkinkan kita merencanakan rute atau membuat pilihan-pilihan dan mengetahui ke mana kita akan pergi dan di mana kita berada, mengumpulkan sejumlah besar data di suatu tempat, mendorong pemecahan masalah dengan membiarkan kita melihat jalan-jalan terobosan kreatif baru, dan menyenangkan untuk dilihat, dibaca, dicerna dan diingat.

Konsep ini dikategorikan ke dalam teknik kreatif, karena pembuatan Mind Mapping ini membutuhkan pemanfaatan imajinasi dari si pembuatnya. Siswa yang kreatif akan lebih mudah membuat Mind Mapping ini. Begitu pula, dengan semakin seringnya siswa membuat Mind Mapping, dia akan semakin kreatif. Sebuah mind map memiliki sebuah ide atau kata sentral, dan ada 5 sampai 10 ide lain yang keluar dari ide sentral tersebut. Mind Mapping sangat efektif bila digunakan untuk memunculkan ide terpendam yang siswa miliki dan membuat asosiasi di antara ide tersebut. Catatan yang siswa buat membentuk sebuah pola gagasan yang saling berkaitan, dengan topik utama ditengah 
dan sub topik dan perincian menjadi cabang-cabangnya, teknik ini dikenal juga dengan nama Radian Thinking (Deporter dan Hernacki, 2011: 152).

Mind Mapping merupakan tehnik penyusunan catatan demi membantu siswa menggunakan seluruh potensi otak agar optimum. Caranya, menggabungkan kerja otak bagian kiri dan kanan. Metode ini mempermudah memasukan informasi kedalam otak dan untuk kembali mengambil informasi dari dalam otak. Mind Mapping merupakan teknik yang paling baik dalam membantu proses berfikir otak secara teratur karena menggunakan teknik grafis yang berasal dari pemikiran manusia yang bermanfaat untuk menyediakan kunci-kunci universal sehingga membuka potensi otak. (Prayudi: 2008). Dengan metode Mind Mapping siswa dapat meningkatkan daya ingat hingga $78 \%$. Peta pikiran yang dibuat oleh siswa dapat bervariasi setiap hari. Hal ini disebabkan karena berbedanya emosi dan perasaan yang terdapat dalam diri siswa setiap harinya. Suasana menyenangkan yang diperoleh siswa ketika berada di ruang kelas pada saat proses belajar akan mempengaruhi penciptaan peta pikiran. Tugas guru dalam proses belajar adalah menciptakan suasana yang dapat mendukung kondisi belajar siswa terutama dalam proses pembuatan Mind Mapping (Iwan Sugiarto, 2004: 76).

Semua mind map mempunyai kesamaan. Semuanya menggunakan warna. Semuanya memiliki struktur alami yang memancar dari pusat. Semuanya menggunakan garis lengkung, simbol, kata dan gambar yang sesuai dengan satu rangkaian Turan yang sederhana, mendasar, alami, dan sesuai dengan cara kerja otak. Dengan mind map, daftar informasi yang panjang bisa dialihkan menjadi diagram warna-warni, sangat teratur dan mudah diingat yang bekerja selaras dengan cara kerja alami otak dalam melakukan berbagai hal (Buzan, 2005:6). Rose dan Malcolm menambahkan strategi visual ini mempunyai beberapa ciri, diantaranya sebagai berikut:

1. Mengingat orang melalui penglihatan, mengingat kata-kata dengan melihat tetapi perlu waktu yang lebih lama untuk mengingat susunan atau urutan abjad jika tidak disebutkan awalnya.

2. Jika memberi atau menerima penjelasan arah lebih suka memakai peta/gambar.

3. Aktifitas reatif: menulis, menggambar, melukis merancang.

4. Mempunyai ingatan visual yang bagus, dimana ketika kita ingat saat meninggalkan sesuatu dalam beberapa hari yang lalu. (Rose dan Malcolm, 2006: 77)

Menurut Buzan, teknik pembuatan catatan dan pengelompokan pikiran yang dirancang untuk memenuhi kebutuhan seluruh otak yang harus menyertakan tidak hanya kata-kata, angka, rangkaian dan juga garis-garis tetapi juga dengan warna, gambar-gambar, dimensi, simbol-simbol itulah peta pikiran atau Mind Mapping (Buzan, 2003: 122).

Terlebih dahulu siapkan selembar kertas kosong yang diatur dalam posisi landscape kemudian tempatan topik yang akan dibahas di tengah-tengah halaman kertas dengan posisi horizontal. Usahakan menggunakan gambar, simbol atau kode pada Mind Mapping yang dibuat. Dengan visualisasi kerja otak kiri yang bersifat rasional, numerik dan verbal bersinergi dengan kerja otak kanan yang bersifat imajinatif, emosi, kreativitas dan seni. Dengan ensinergikan potensi otak kiri dan kanan, siswa dapat dengan lebih mudah menangkap dan menguasai materi pelajaran. 
Upaya Meningkatkan Daya Ingat Tentang Materi Keseimbangan Lingkungan Dengan Menerapkan Teknik Mind Mapping, Siti Rochanah

Teknik Mind Mapping sangat baik digunakan untuk pengetahuan awal siswa atau untuk menemukan alternatif jawaban. Dipergunakan dalam kerja kelompok secara berpasangan (2 orang). Langkah-langkah pembelajarannya:

1. Guru menyampaikan kompetensi yang ingin dicapai.

2. Guru menyajikan materi sebagaimana biasa.

3. Untuk mengetahui daya serap siswa, bentuklah kelompok berpasangan dua orang.

4. Menugaskan salah satu siswa dari pasangan itu menceritakan materi yang baru diterima dari guru dan pasangannya mendengar sambil membuat catatan-catatan kecil, kemudian berganti peran. Begitu juga kelompok lainnya.

5. Menugaskan siswa secara bergiliran/diacak menyampaikan hasil wawancaranya dengan teman pasangannya. Sampai sebagian siswa sudah menyampaikan hasil wawancaranya.

6. Guru mengulangi/menjelaskan kembali materi yang kiranya belum dipahami siswa.

7. Kesimpulan/penutup

Ada banyak manfaat atau keunggulan yang dapat diraih bila siswa menggunakan teknik mencatat mind map (peta pikiran) ini dalam kegiatan pembelajarannya, diantaranya meningkatkan kreativitas dan aktivitas individu maupun kelompok, memudahkan otak memahami dan menyerap informasi dengan cepat, meningkatkan daya ingat, mengakomodasi berbagai sudut pandang terhadap suatu informasi, memusatkan perhatian siswa, serta mengaktifkan seluruh bagian otak.

Kelebihan penerapan teknik ini yaitu penerapan yang relatif cepat, dapat digunakan untuk mengorganisasikan ide-ide yang muncul secara spontan, proses mengganbar diagram bisa memunculkan ide-ide yang lain, dan gambar yang sudah terbentuk bisa menjadi panduan untuk menulis. Sedangkan kelemahannya adalah hanya siswa yang aktif yang terlibat, tidak sepenuhnya siswa belajar, dan jumlah detail informasi tidak dapat dimasukkan.

\section{METODE}

\section{Setting Penelitian}

Sesuai dengan jenis penelitian yang dipilih, yaitu penelitian tindakan, maka penelitian ini menggunakan model penelitian Tindakan dari Kemmis dan Taggart (dalam Arikunto, 2002: 83), yaitu berbentuk spiral dari siklus yang satu ke siklus yang berikutnya. Setiap siklus meliputi planning (rencana), action (tindakan), observation (pengamatan), dan reflection (refleksi). Langkah pada siklus berikutnya adalah perencanaan yang sudah direvisi, tindakan, pengamatan, dan refleksi. Sebelum masuk pada siklus I dilakukan tindakan pendahuluan yang berupa identifikasi permasalahan.

\section{Subyek Penelitian}

Penelitian ini dilaksanakan oleh penulis di SD Negeri Kendangsari I/276 dengan alamat Jl. Kendangsari Blok S No. 26 Kecamatan Tenggilis Mejoyo Kota Surabaya. Pelaksanaan penelitian dan perbaikan dijadwalkan oleh penulis dengan rincian jadwal sebagai berikut: 
Tabel 1. Waktu Pelaksanaan Tindakan

\begin{tabular}{|c|c|}
\hline Siklus & Waktu Pelaksanaan \\
\hline Siklus 1 & Senin, 5 dan 12 Oktober 2020 \\
\hline Siklus 2 & Senin, 19 dan 26 Oktober 2020 \\
\hline
\end{tabular}

Kelas yang dijadikan obyek perbaikan dan penelitian adalah Kelas 4-C dengan jumlah siswa sebanyak 39 siswa

\section{Teknik Pengumpulan Data}

Teknik pengumpulan data yang digunakan Penulis dalam Penelitian Tindakan Kelas ini adalah (1) Observasi. Observasi adalah studi sistematis yang di sengaja tentang fenomena-fenomena social dan gejala-gejala psikis dengan pengamatan. Oleh karena itu Penulis harus terlibat secara langsung dalam Penelitian Tindakan Kelas karena status penulis sendiri adalah sebagai guru kelas pada subyek penelitian, (2) Pendekatan partisipatif. Pendekatan ini digunakan untuk lebih menjadikan suasana dalam kegiatan belajar mengajar lebih hidup, sehingga penulis terlibat secara langsung atau berpartisipasi dalam hal pengumpulan yang diinginkan dan terkadang pula mengarahkan tindakan atau arahan yang mengarah kepada data yang diinginkan oleh peneliti. (3) Penilaian Hasil Belajar. Data yang telah diperoleh dilapangan akan diukur oleh penulis dengan menggunakan pedoman lembar observasi perilaku siswa dan presentase hasil tugas serta nilai ulangan harian kelas.

Untuk mempermudah penulis dalam mengumpulkan data yang diperoleh tidak hilang maka penulis melakukan perekaman dengan cara membuat catatan dari hasil yang telah diperoleh selama proses penelitian. Teknik perekaman yang dilakukan adalah dengan membuat catatan-catatan pada pedoman obserfasi berdasarkan perkembangan siswa setiap siklus, yakni siklus I, II dan seterusnya.

\section{Validasi Data}

Untuk mendapatkan data yang mendukung dan sesuai dengan karakteristik fokus permasalahan dan tujuan penelitian perlu validasi data. Teknik validasi yang digunakan dalam penelitian ini adalahtriangulasi data. Triangulasi data yaitu mengecek keabsahan (validasi) data dengan mengkonfirmasikan data yang sama dari sumber yang berbeda untuk memastikan keabsahan (derajat kepercayaan). Dari guru dilakukan pada saat penerapan model pembelajaran kooperatif picture and picturedan dengan data yang dijaring melalui lembar observasi teman guru/sejawat dan kepala sekolah. Sedangkan dari siswa dilakukan kuesioner atau wawancara. Dari ahli dilakukan pada saat bimbingan mengenai temuan-temuan penelitian dan penyusunan laporan.

\section{Teknik Analisis Data}

Dalam penelitian ini teknik analisis datanya adalah mengunakan pendekatan metode kualitatif untuk menganalisis keaktifan dan kreatifitas siswa, dan juga menggunakan metode kuantitatif untuk menganalisis tingkat keberhasilan siswa dalam proses belajar, melalui cara pengambilan data hasil pretes dan post test dengan memberi skor pada hasil tes. 
Upaya Meningkatkan Daya Ingat Tentang Materi Keseimbangan Lingkungan Dengan Menerapkan Teknik Mind Mapping, Siti Rochanah

Analisis data kuantitatif diperoleh dari hasil tes siswa yang bertujuan untuk mengetahui pengetahuan siswa tentang materi pelajaran dari setiap siklus, di mana siswa secara individu telah belajar tuntas atau berhasil apabila sekurang-kurangnya mendapat nilai 2,8 berdasarkan indikator daya ingat yang diterapkan melalui teknik Mind Mapping.

Standar penentuan ketuntasan belajar siswa menurut Sudjana (2006:109) sebagai berikut:

$\mathrm{P}=\sum \mathrm{f} \times 100 \%$

$\mathrm{N}$

Keterangan:

$\mathrm{P} \quad=\quad$ Persentase ketuntasan secara individu.

$\sum \mathrm{f}=\quad$ Jumlah nilai yang diperoleh siswa.

$\mathrm{N}=\quad$ Nilai maksimal.

Sedangkan untuk mencari persentase ketuntasan secara klasikal menggunakan rumus:

$\mathrm{P}=\sum \mathrm{n} \times 100 \%$

$\mathrm{N}$

Keterangan:

$\mathrm{P}=\quad$ Persentase ketuntasan belajar secara klasikal.

$\sum \mathrm{n}=\quad$ Jumlah siswa yang mendapat nilai $\geq 2,8$.

$\mathrm{N}=$ Jumlah siswa seluruhnya.

Data pengamatan dianalisis dengan menghitung rata-rata pada setiap siklus yang dilaksanakan, selanjutnya nilai rata-rata tersebut diklasifikasikan dengan kriteria sebagai berikut:

$3,1-4$ = Sangat baik.

$2,1-3$ = Baik.

$1,1-2$ = Cukup.

$0,1-1=$ Kurang

\section{Indikator Kinerja}

Indikator kinerja disusun berdasarkan aktivitas siswa selama kegiatan belajar mengajar yang mengindikasikan munculnya keingintahuan mereka sehingga meningkatkan daya ingat materi Keseimbangan Lingkungan sebagaimana terinci dalam tabel berikut:

Tabel 2. Indikator Kinerja

\begin{tabular}{|c|l|}
\hline No & \multicolumn{1}{|c|}{ Indikator yang Diobservasi } \\
\hline 1 & Memahami kompetensi yang akan dicapai \\
\hline 2 & Mendengarkan penjelasan tentang cara membuat Mind Mapping \\
\hline 3 & Membuat Mind Mapping materi \\
\hline 4 & Menjelaskan materi berdasarkan Mind Mapping \\
\hline 5 & Melakukan refleksi \\
\hline
\end{tabular}




\section{Diskusi}

\section{Deskripsi Per Siklus}

Pembelajaran pada siklus I dilaksanakan dalam waktu 2 × 2 × 25 menit. Pertemuan siklus I direncanakan pada tanggal 5 dan 12 Oktober 2021. Materi pembelajaran pada siklus ini adalah Keseimbangan Lingkungan (berdasarkan buku guru Kelas 4-C kurikulum 2013 tema 3). Peduli Terhadap Makhluk Hidup. Penilaian dilakukan dengan menggunakan teknik tes tertulis dengan butir soal atau tugas sebagaimana termaktub dalam buku siswa. Kegiatan pembelajaran pada siklus I meliputi kegiatan awal, kegiatan inti dan kegiatan akhir. Kegiatan pembelajaran yang dilakukan ini sesuai dengan langkah-langkah teknik Mind Mapping sebagai berikut:

1. Guru menyampaikan kompetensi yang ingin dicapai.

2. Guru menyajikan materi sebagaimana biasa.

3. Untuk mengetahui daya serap siswa, bentuklah kelompok berpasangan dua orang.

4. Menugaskan salah satu siswa dari pasangan itu menceritakan materi yang baru diterima dari guru dan pasangannya mendengar sambil membuat catatan-catatan kecil, kemudian berganti peran. Begitu juga kelompok lainnya.

5. Menugaskan siswa secara bergiliran/diacak menyampaikan hasil wawancaranya dengan teman pasangannya. Sampai sebagian siswa sudah menyampaikan hasil wawancaranya.

6. Guru mengulangi/menjelaskan kembali materi yang kiranya belum dipahami siswa.

7. Kesimpulan/penutup

Penilaian observer tentang Aktivitas Guru pada Siklus I termasuk dalam kategori baik. Hal ini terlihat pada tahap pembelajaran kegiatan awal. Hal ini dipengaruhi oleh kemampuan guru dalam memotivasi siswa. Pada tahap kegiatan inti guru masih belum bisa melakukan improvisasi dan belum mengerti tentang langkah-langkah penyelesaian dalam pemecahan. Maka dari tinjauan ini, observer menyimpulkan bahwa pada tahap kegiatan Siklus I, tampaknya guru masih perlu bimbingan dalam hal mengimprovisasi langkah demi langkah dari metode yang digunakan. Pada siklus I penerapan teknik Mind Mapping banyak sekali perubahan yang dialami siswa, khususnya mereka yang cenderung memiliki materi Keseimbangan Lingkungan yang rendah.

Berdasarkan hasil observasi dapat disimpulkan bahwa pada siklus I rata-rata nilai materi Keseimbangan Lingkungan siswa adalah 2,85 dan rata-rata kemampuan siswa dalam melaksanakan teknik Mind Mapping adalah 13,8 atau 69\%. Hal ini bila diinterpretasikan ke dalam tabel interpretasi dengan rata-rata 2,84 maka termasuk ke dalam kategori baik. Adapun ketuntasan klasikal pada siklus I sebesar 56,4\% dengan kategori cukup.

Selain bagi siswa, teknik Mind Mapping ini merupakan hal yang baru bagi penulis sehingga sempat agak bingung bagaimana cara menjelaskan aturan pelaksanaannya pada siswa. Di samping 
itu, penulis sempat meragukan apakah dengan model dan model pembelajaran ini daya ingat materi Keseimbangan Lingkungan berubah.

Pembelajaran pada siklus II dilaksanakan dalam waktu 2 × 2 × 25 menit. Pertemuan siklus II direncanakan pada tanggal 19 dan 26 Oktober 2021. Materi pembelajaran pada siklus ini adalah Keseimbangan Lingkungan. Penilaian dilakukan dengan menggunakan teknik tes tertulis dengan butir soal atau tugas sebagaimana termaktub dalam buku siswa. Kegiatan pembelajaran pada siklus I meliputi kegiatan awal, kegiatan inti dan kegiatan akhir. Kegiatan pembelajaran yang dilakukan ini sesuai dengan langkah-langkah teknik Mind Mapping sebagai berikut:

1. Guru menyampaikan kompetensi yang ingin dicapai.

2. Guru menyajikan materi sebagaimana biasa.

3. Untuk mengetahui daya serap siswa, bentuklah kelompok berpasangan dua orang.

4. Menugaskan salah satu siswa dari pasangan itu menceritakan materi yang baru diterima dari guru dan pasangannya mendengar sambil membuat catatan-catatan kecil, kemudian berganti peran. Begitu juga kelompok lainnya.

5. Menugaskan siswa secara bergiliran/diacak menyampaikan hasil wawancaranya dengan teman pasangannya. Sampai sebagian siswa sudah menyampaikan hasil wawancaranya.

6. Guru mengulangi/menjelaskan kembali materi yang kiranya belum dipahami siswa.

7. Kesimpulan/penutup.

Penilaian observer tentang Aktivitas Guru pada Siklus II termasuk dalam kategori sangat baik. Hal ini terlihat pada tahap pembelajaran kegiatan awal. Hal ini dipengaruhi oleh kepandaian guru dalam memotivasi siswa. Pada tahap kegiatan inti guru telah berhasil melakukan improvisasi pada langkah-langkah penyelesaian. Maka dari tinjauan ini, observer menyimpulkan bahwa pada tahap kegiatan Siklus II secara global berjalan dengan lancar.

Berdasarkan hasil observasi dapat disimpulkan bahwa pada siklus II rata-rata nilai materi Keseimbangan Lingkungan siswa adalah 3,10 dan rata-rata kemampuan siswa dalam melaksanakan teknik Mind Mapping adalah 15,2 atau 76\%. Hal ini bila diinterpretasikan ke dalam tabel interpretasi dengan rata-rata 3,10 maka termasuk ke dalam kategori sangat baik. Adapun ketuntasan klasikal pada siklus I sebesar $82,1 \%$ dengan kategori sangat baik.

Selain bagi siswa, teknik Mind Mapping ini merupakan hal yang menyenangkan bagi penulis sehingga pembelajaran menjadi hidup dan aktivitas siswa dalam belajar semakin meningkat. Teknik Mind Mapping ini harus dilaksanakan secara berkesinambungan sebagai upaya pembiasaan bagi siswa.

\section{Diskusi}

Penerapan teknik Mind Mapping sangat efektif digunakan untuk meningkatkan pemahaman pada tema ekosistem siswa Kelas 4-C SDN Kendangsari I/276 Surabaya. Hal ini dibuktikan dengan meningkatnya siswa yang mencapai kriteria ketuntasan minimal (KKM) atau telah memiliki daya 
serap $\geq 2,8$ pada materi, dan juga meningkatnya ketuntasan klasikal yang tercapai apabila paling sedikit $75 \%$ siswa di kelas tersebut telah tuntas belajar.

Dalam upaya peningkatan pemahaman dalam penelitian tindakan ini telah dilaksanakan dalam dua tahap yang menunjukkan progresifitas ditilik dari ketercapaian individu maupun klasikal. Secara individu, rata-rata daya ingat mengalami kenaikan yang signifikan dari 2,17 (kondisi prasiklus) menjadi 3,10 atau 25\% sedangkan secara klasikal, rata-rata ketuntasan mengalami kenaikan yang signifikan dari 13,2\% (kondisi prasiklus) menjadi 82,1\% atau kenaikan 68,9\%.

Tentu saja progresifitas ini membutuhkan upaya tindak lanjut agar dapat dibentuk pembiasaan dan budaya ilmiyah pada diri siswa ini melalui penerapan teknik Mind Mapping maupun penerapan model, metode, strategi dan teknik serupa lainnya. Untuk mempermudah upaya tersebut seharusnya pendidik senantiasa mengembangkan kompetensi profesionalismenya dalam rangka mencari inovasi dan kreatifitas terbaru tentang model, metode, strategi dan teknik pembelajaran.

\section{KESIMPULAN}

Berdasarkan hasil penelitian di atas, maka dapat disimpulkan bahwa ada peningkatan daya ingat materi Keseimbangan Lingkungan melalui penerapan teknik Mind Mapping pada siswa Kelas 4-C SD Negeri Kendangsari I/276 Surabaya. Peningkatan daya ingat materi Keseimbangan Lingkungan melalui penerapan teknik Mind Mapping pada siswa Kelas 4-C SD Negeri Kendangsari I/276 Surabaya rata-rata sebesar $25 \%$.

Upaya peningkatan daya ingat materi Keseimbangan Lingkungan melalui penerapan teknik Mind Mapping dapat dijadikan acuan untuk mengadakan penelitian selanjutnya dengan sudut permasalahan berbeda atau solusi berbeda dengan permasalahan serupa. Berdasarkan simpulan hasil penelitian tersebut, peneliti memberikan saran agar dalam pembelajaran guru sebaiknya memakai berbagai macam metode, yang sesuai dengan tingkat pengetahuan siswa sehingga tidak bosan dan menerima pelajaran dengan baik. Kemudian dalam pemberian tugas haruslah menggunakan banyak variasi, sehingga diharapkan siswa dalam mengerjakan tugasnya bisa bersemangat dan dapat memahami maksud dan tujuan dari tugas tersebut. Selain itu hendaknya gekali-kali memberikan reward, untuk memacu semangat siswa

\section{UCAPAN TERIMA KASIH}

Terimakasih kami ucapkan kepada Kepala Sekolah dan Guru-guru di SDN Kendangsari I/276 Surabaya yang telah memberikan kesempatan kepada peneliti dalam melaksanakan penelitian. Tidak lupa rasa terimakasih juga kami sampaikan kepada siswa yang telah ikut berpartisipasi dalam melaksanakan penelitian ini.

\section{REFERENSI}

Abdulloh, 2018. Pembelajaran IPA di SD. Jakarta: Universitas Terbuka 
Upaya Meningkatkan Daya Ingat Tentang Materi Keseimbangan Lingkungan Dengan Menerapkan Teknik Mind Mapping, Siti Rochanah

Ahmadi, A. 2004.Psikologi Umum Cet I. Jakarta: PT. Rineka Cipta.

Arikunto, Suharsimi. 2003. Dasar-dasar Evaluasi Pendidikan. Sinar Grafika Offset. Jakarta.

Atkinson \& Atkinson. 2002. Pengantar Psikologi Edisi Kedelapan Jilid I. Jakarta: Erlangga

Buzan, Tony. 2003. Use Both Sides of Your Brain. Surabaya: Ikon.

Buzan, Tony. 2005. Buku Pintar Mind Maps. Jakarta: Gramedia.

Buzan, Tony dan Barry. 2008. Memahami Peta Pikiran. Bandung: Interaksara

Deporter \& Hernacki. 1999. Quantum Learning: Membiasakan Belajar Nyaman dan Menyenangkan. Bandung: Kaifa.

Markowitz, K, M.A. \& Jensen Eric, M.A. (2002). Otak Sejuta Gigabyte: Buku Pintar Membangun Ingatan Super (Terjemahan). Bandung: Kaifa.

Nana Sudjana. (2011). Penilaian Hasil Proses Belajar Mengajar. Bandung: PT Remaja Rosdakarya.

Poerwodarminto. 1991. Kamus Umum Bahasa Indonesia. Jakarta: Bina Ilmu.

Prayudi: 2008. Pengaruh Penggunaan Strategi Pembelajaran Mind Mapping terhadap Prestasi belajar Jakarta

Rose, Colin dan Malcolm J. 2006. Accelered Learning. Bandung: Nusantara

Santrock, J.W. 2005. Adolescence, Perkembangan Remaja. Jakarta: Erlangga.

Sugiarto, Iwan. 2004. Mengoptimalkan Daya Kerja Otak Dengan Berfikir Holistik dan Kreatif. Jakarta: Gramedia Pustaka Utama.

Sumaji, dkk. (1998). Pendidikan Sains yang Humanistis. Yogyakarta: Kanisus

Suyoso. 1998. Pengembangan Pendidikan IPA SD. Jakarta: Dirjen dikti.

Svantesson. Ingemar.2004 Learning Maps and Memori Skills.Jakarta: Gramedia.

Usman. (2000). Menjadi Guru Profesional. Bandung: PT. Remaja Rosdakarya.

Wade, C. 2008. Psikologi. Jakarta: Erlangga.

Walgito. (2004). Pengantar Psikologi Umum. Yogyakarta: Andi

Wulandari, Tri. 2009. Perbedaan Kemampuan Mengingat Ditinjau Dari Gaya Belajar. Skrips. Surakarta: Fakultas Psikologi Universitas Muhammadiyah. 